\title{
Banking Sector Reforms and Agricultural Sector Performance in Nigeria
}

\author{
Yekeen Oku. Abdul-Maliq ${ }^{1}$, Jude Igyo Ali², Henry Yua ${ }^{3, *}$ \\ ${ }^{1}$ Department of Banking and Finance, University of Abuja, Abuja, Nigeria \\ ${ }^{2}$ Benue State Internal Revenue Service, Makurdi, Nigeria \\ ${ }^{3}$ Department of Banking and Finance, Nigerian Army College of Environmental Science and Technology, Makurdi, Nigeria \\ Email address: \\ yekeen.abdulmaliq@uniabuja.edu.ng(Y. O. Abdul-Maliq), alijude2003@gmail.com (J. I. Ali), henryyua@gmail.com (H. Yua) \\ ${ }^{*}$ Corresponding author
}

\section{To cite this article:}

Yekeen Oku. Abdul-Maliq, Jude Igyo Ali, Henry Yua. Banking Sector Reforms and Agricultural Sector Performance in Nigeria. Journal of Business and Economic Development. Vol. 6, No. 3, 2021, pp. 176-183. doi: 10.11648/j.jbed.20210603.17

Received: August 14, 2021; Accepted: August 26, 2021; Published: September 23, 2021

\begin{abstract}
This paper examines the effect of banking sector reforms on the growth of agricultural output in Nigeria from 1986 to 2019, with the specific objective of determining the extent to which aggregate bank credit to the agricultural sector (ABCAS), which was expected to be occasioned by banking sector reforms, in conjunction with other reform variables, impacted output growth in the agricultural sector in the period under study. The study utilizes 34 years annual time series data obtained from NBS and CBN data bases. Two-Stage Least Squares (2SLS), technique, Breusch-Godfrey LM test of autocorrelation and the ARCH test were used to ascertain the short and long run relationships among ABCAS, DMBLDR, IRS and ASOP. Hypotheses are tested at 5\% level of significance. Results show that $96 \%$ of the variation in the dependent variable, judging by the Adjusted $\mathrm{R}^{2}$, is attributable to the combined effect of the independent variables. Analysis also reveals that aggregate bank credit to the agricultural sector, (ABCAS), and real effective exchange rate, (REER), exhibit positive and significant relations with agricultural output growth with co-efficient of 29.01 and 33.10 respectively. The study therefore canvasses for banking system structure that prioritizes agricultural financing anchored on manufacturing: - (agro-business; focus), to engender agricultural value-chain creation and enhancement, preferably targeting export of finished agro-allied products.
\end{abstract}

Keywords: Aggregate Bank Credit, Agricultural Sector, Agric Sector Output, Interest Rate Spread, Reform

\section{Introduction}

The financial-growth nexus debate has elicited considerable attention in both the academia as well as among policy makers for some many decades now. This perhaps informs the seeming continuous reforms in the banking sectors across the globe, Nigeria inclusive. The theoretical and conceptual foundation linking banking sector reforms and economic growth, can be traced back to the works of Beck, Demirgüç-Kunt, \& Levine; Bagehot and Schumpeter, all of whom stress the significance of banking sector in making available required capital to fund economic activities, especially, the real sector which is the engine room of economic growth $[6,7,25,23]$.

In view of the above, the Nigerian government has embarked on series of banking reforms since the mid 1980 aimed at enhancing efficiency in banking service delivery, promoting investment, and ensuring efficiency in resource allocation $[3,18,27]$.

The importance of the agricultural sector in the economic grow process has been and is still recognized world-wide. In the Nigerian situation, the agricultural sector was the mainstay of the economy in the pre and immediate postcolonial periods $[14,2,16]$. But like the structural change theory of economic growth posits, in the course of time, every nation has to modernize, transform from agrarian to industrial society Todaro and Smith, citing two-sector model structural change theories as examples of this necessary metamorphic process [28].

To catalyze this form of transition, capital, in the form of domestic, foreign direct as well as portfolio investments, are needed in large quanta. Strong, efficient and dynamic financial/banking system development is usually a 
prerequisite in this regard. Banking system reforms in Nigeria have always been anchored on or targeted at this 'opening up' of the financial flood-gate to the economy and especially the agricultural sector. The Nigerian banking sector has witnessed series of reforms. In fact, Okafo described the first half century of banking in Nigeria as a continuum of reforms [21]. These reforms have always been intended to ensure a formidable banking system that allows free flow and efficient allocation of scarce financial resources; to attract the much-needed finance for development of the agricultural sector and the economy at large.

\section{Literature Review}

\subsection{Conceptual Review}

\subsubsection{Banking Reforms}

Banking reforms refers to regular changes in rules and regulations governing or guiding entry into as well as the operations of banks and other financial institutions. Banking regulation per se; and reforms thereof, are usually aimed at achieving some macroeconomic objectives or accelerate the rate at which such achievements and are made. Such macroeconomic objectives include GDP growth, price stability, reduction in unemployment among others. Banking reforms often arises as a result of banking or financial crises. Nevertheless, some reforms are undertaken independent of banking crisis. Irrespective of the cause, banking reforms are applied to strengthen the banking system, embrace globalization, encourage healthy competition, exploit economies of scale, adopt advanced technologies, raise efficiency and improve profitability and what not. Ultimately, the goal of banking reform is to strengthen the intermediation capabilities of banks and to ensure that they are able to perform their developmental roles in enhancing economic growth. Banking reforms in Nigeria, especially since the 1980s and more so, the 2004/2005, 2007, 2017, etc. reforms have been embarked upon to enable the banking system develop the required capacities and capabilities as well as flexibility to support the nation's economic development efforts [18].

\subsubsection{Economic Growth}

Economic growth refers to increase in a nation's outputs of goods and services from one accounting period (usually a year) to another. According to Gheernert, and Mansour, economic growth refers to an increase production in society over time [10]. It is the rate at which a country's Gross Domestic Product (GDP) is increasing from year to year. According to Jhingan, economic growth is related to a quantitative sustained increase in the country's per capita output or income accompanied by expansion in its labour force, consumption, capital and the volume of trade [13].

\subsubsection{Agricultural Sector Growth}

Harris, and Fuller, say agriculture subsumes so many things that include and or are related to field or land tillage [12]. According to them, agriculture encompasses cultivation, [animal domestication] husbandry, horticulture, arboriculture and vegeculture, as well as forms of livestock management.

Agriculture has also been defined as the production of food and livestock and the purposeful tendering of plants and animals. Agricultural sector growth may therefore be defined as increases in the production of crops, livestock, fishery (aquaculture) and other related or similar products.

\subsection{Theoretical Review}

The nexus between banking sector reforms and growth of Agricultural sector is examined on the foundation of several theories which include: financial liberalization theory, Keynesian theory of finance and economic growth and proconcentration theory. This study relies on the Keyns and financial liberalization theories. This is because careful perusal and reasoning reveals that other theories have their roots or emphasis these two theories. Beside this, the theory of finance and economic growth and financial liberalization theory, explain key parameters or variables of financial reforms that result in economic growth.

\subsubsection{Financial Liberalization Theory}

Financial liberalisation theory stems from the works of anti-repressionist writers like, McKinnon and Shaw who attribute economic development in the developed countries to liberal financial systems $[20,26]$. It is argued that financial liberalisation is a necessary ingredient in the generation of high saving rates and investment [20]. Shaw canvas the idea that real growth in financial institutions arising from deregulation of the financial system, provides domestic investors with the incentive to save and borrow, thus enabling them to attract more equity and thereby lowering the cost of borrowing [26]. Gibson, and Tsakalotos in same view argue that financial liberalisation is necessary for banks to operate efficiently and to provide new opportunities for financing the economy [11].

\subsubsection{Keynesian Theory of Finance and Economic Growth}

Based on Keyns general theory of unemployment, interest and money; this theory suggests that financial system (instruments, markets, and institutions), exist to mitigate (or reduce) the impact of information asymmetry and transaction costs; thereby influencing savings rate, investment decisions, technological innovations, and therefore, long-run growth [17]. The theory explains further that the financial system ameliorates market frictions through its basic functions which, taken together, affect growth and development through two channels: capital accumulation and technological innovations. In this regard, market frictions motivate the emergence of financial market operators and intermediaries that perform the basic functions which affect growth and development through capital accumulation and technological development [19].

Regarding capital accumulation, the theory emphasizes a steady-state per capita growth as being generated via capital externalities or capital goods produced with constant returns to scale but without the use of non-reproducible factors. Thus, 
the functions performed by financial system affect steady state growth by influencing the savings rate and or through reallocation of savings among different capital producing technologies. On technological innovation, the theory emphases new production process and goods. Here, the financial functions affect steady-state growth by altering the rate of technological innovation.

\subsubsection{Pro-Concentration Theory}

Bank concentration refers to the degree of control of economic activity by large banks [5]. Pro-concentration theory suggests that the increase in concentration level could be due to considerable size enlargement of the dominant firms. Proponents of the pro-concentration theory argue that economies of scale drive bank capitalization, mergers and acquisitions such that increase in concentration can be used to achieve improvement and efficiency in the banking sector. Proponents of this theory are also of the opinion that a less concentrated banking sector with many small banks is more prone to financial crises than a concentrated banking sector with a few large banks. This is because economies of scale drive bank mergers and acquisitions (increasing concentration), so that increased concentration goes hand-inhand with efficiency improvement. To strengthen this point, Omankhanlen posits that the small size of most banks, each with expensive headquarters, separate investments in soft and hardware's, heavy fixed asset cost and operating expenses, with a lot of branches in few commercial centers lead to very high average cost for the industry [24].

On the other hand, a few large banks are easier to be monitored than many small banks, so, corporate control will be more effective and the risk of contagion less pronounced in a concentrated banking system than otherwise [6]. The size of a banks is determined largely by its financial capacity.

\subsection{Empirical Review}

A substantial body of empirical research works has examined the link between banking sector reforms and growth of Agricultural sector in Nigeria. Using different data sets and statistical models, this study has found diverse results and effects across different economies. For instance, Uzomba, Chukwu, Jumbo, \& Nwankwo, carried out a study on the impact and the determinants of Deposit Money Banks' loans and advances granted to agricultural sector in Nigerian sector from 1980 to 2011 [29]. The study employed the multiple OLS regression, Philips- Perron, Unit Root Stationarity Test, Johnansen Co-integration, Parsimonious Error Correction Mechanism and Granger Causality Test with the help of E-views statistical package. The result was that; banks loans and advances did make positive impact on the agricultural sector of Nigeria within the period of review. The study therefore recommended that the Federal Government and Monetary Authorities should respectively use expansionary fiscal and monetary policies to expand the volume of loans and advances to agricultural sector in Nigeria as a matter of policy; to stimulate increase in output of agricultural sector and also contribute to economic growth.
Anthony, O., Gabriel, E. E. and Arikpo, O. F., investigate the role of deposit money banks credit on the growth of the agricultural sector in Nigeria from 1988 to 2011 [4]. An expost facto research design was adopted for the study. Data were sourced principally from CBN Statistical Bulletin. The Data were analyzed using the ordinary least square multiple technique. Result from the analysis revealed that both deposit money banks loans and the agricultural credit guarantee scheme fund had positive relationships with the output of the agricultural sector. The study however discovered that agricultural credit guarantee scheme funds relationship with output was insignificant. Other findings include that deposit money bank lending rate had a negative but insignificant relationship with output of the agricultural sector in Nigeria. Based on these findings, the study recommended that loans and finances to the agricultural sector should be increased while lending rate should be reduced. Also, the conditions and farmers to access agricultural credit guarantee scheme fund should be reviewed.

Adesanya, B. and Obademi, O. E, examine the effect of banking reforms on economic growth of Nigeria. Using time series data from 1994 to 2014 with the aid of ordinary least square they found that banking sector developments had significant effect on the activities of the economy. However, according to them, this does not imply that the reforms in the banking sector are solely responsible for the sector being better off. The study recommended an improvement in financial intermediation, monetary policy intervention and consistent regulations as necessary ingredients for stimulating investment, raising productive capacity and fostering economic growth [1].

Chris, O. U, Mbat, D. O and Stephen, B. D., examined the effect of commercial banks' credit on agricultural output in Nigeria. Four research variables of agricultural output, measured by agricultural gross domestic product, commercial banks' credit to agricultural sector, government expenditure on agriculture, agricultural credit guarantee scheme fund, interest rate, represented by lending rate were considered in the study. Data for the study was collected from CBN Statistical bulletin. Using ordinary least squares regression technique, the result showed that there is a positive and significant relationship between agricultural credit guarantee scheme fund, government expenditure and agricultural production in Nigeria; implying that an increase in agricultural credit guarantee scheme, government expenditure and commercial banks credit fund could lead to an increase in agricultural production in Nigeria. However, the study found a negative relationship between interest rate and agricultural output indicating that an increase in the rate of interest charged farmers for funds borrowed discouraged many farmers from borrowing and thus less agricultural investment. The study recommended proper funding of the agricultural sector by the government and the private sector at a reduced cost of capital for optimum growth [8].

Ali, J I., Jatau S. and Ekpe, M. J., examine the impact of deposit money banks' credit on agricultural output in Nigeria from 1981 to 2014. Using ordinary least square method for 
data analysis and other diagnostic analysis, the findings revealed that deposit money banks' credit significantly and positively affected agricultural output while the result for deposit money banks' lending rate showed that deposit money bank lending rate has an inverse and insignificant impact on Agricultural output. Thus, the study concludes that deposit money banks' credit is a viable source of finance for sustainable growth in the agricultural sector. The study therefore recommends that deposit money banks' should increase the volume of credit facilities to the agricultural sector to sustain food production for the teeming population of Nigeria. They however recommend that lending should be concentrated on the real farmers. Also, the cost of deposit money banks' credit facilities should be subsidized or be reduced to a single digit lending rate for agri-businesses and should have a longer moratorium to ensure effective performance of both agricultural output and the credit facilities [2].

Kareem, R. O, Osisanya, S. O and Isiaq, T. S, examined the effect of commercial banks financing and agricultural sector output in Nigeria for a period of 34 years (1981-2014). The study used real agricultural domestic product and Commercial Bank Loans to agricultural sector. The Ordinary Lease square technique was utilized to estimate the effect of commercial banks financing on agricultural sector output and the results revealed that the total variation in real agricultural gross domestic product is explained by the explanatory variable i.e. commercial bank loans to agricultural sector. Analysis showed that there is a positive relationship between commercial bank loan to agriculture and the real agricultural gross domestic product the study conclude that the commercial bank financing has significant impact on agricultural sector output in Nigeria. The study recommended that commercial bank should increase loan facilities to the agricultural sector to sustain food production for the teeming population of Nigeria [15].

Ekine, D I. and Onukwuru F. M., examine the effect of deposit money banks credit on agricultural sector performance in Nigeria from 1986 to 2016. Analysing data obtained from CBN statistical bulletin; the study used agricultural sector output to proxy agricultural sector performance as the dependent variable whereas Deposit Money Banks' Credit to Agricultural Sector was the major explanatory variable. Interest Rate and Government Expenditure on Agriculture were independent variables. Using Ordinary Least Squares (OLS), co-integration and ECM methods as the analytical tools, the study revealed that there is no co-integrating (or long run) relationship between deposit money banks' credit to agricultural sector and the performance of agricultural sector in Nigeria within the period of study and that Deposit money banks' credit to agricultural sector had a positive and a significant impact on Agricultural Sector performance. Regarding the relationship between Interest Rate and agricultural performance the result showed a negative but insignificant relationship with Agricultural Sector performance as well as that government expenditure had positive but insignificant relationship with agricultural sector performance. Consequently, the study recommended that efforts be made by the government and private sector to encourage or increase investment in the agricultural sector. Also that lending rate on agricultural loans be reviewed and fixed at a rate that would encourage farmers to acquire loans from deposit money banks [9].

Onyema, J. I. and Agada. R. C., examined the contribution of agricultural financing through deposit money banks to the growth of the agricultural sector in Nigeria. Time series data were collected from Central Bank of Nigeria Statistical Bulletin for the period 1981 to 2015. Percentage of agricultural sector gross domestic product to total GDP was used as the dependent variable while percentage of deposit money bank credit to agricultural to total deposit money banks credit, prime lending rate and maximum lending rate were used as the independent variables. Using cointegration test, granger causality test and error correction model to determine the short and long run relationships between the dependent and the independent variables; result showed that deposit money banks credit to agricultural sector is not enough to guarantee a positive contribution to the growth of the agricultural sector. Prime lending rate and maximum lending rate are found to contribute positively to the growth of the agricultural sector. Causality test reveals a unidirectional causal relationship running from independent to the dependent variable. From the regression summary, the study concludes that agricultural financing has no salutary effect on the growth of agricultural sector in Nigeria. The study recommends more concerted efforts that will develop the sector through the use of modern tools and technology, and the removal of other traditional constraints such as land fragmentation, to make the sector more productive to attract more funding by the private sector [22].

Agenson and Eyo, (2019) examined the impact of financial sector reforms on agricultural output in Nigeria. The specific objectives were to; compare the output of the different agricultural sub-sectors in the different reform era, compare the contribution of loans to output of the different agricultural sub-sectors and to analyze the impact of reforms on farmer's output. Data for the study were obtained from Central Bank of Nigeria Statistical bulletin, annual report, federal budget allocation report, annual reports among others. Data were analyzed using both descriptive and inferential statistics. The results showed that agricultural output of the crop sector was consistently higher than that of other agricultural subsectors in virtually all the reform periods; the contribution of loan to output in the livestock and fisheries sub-sectors were consistently below $12 \%$ and $3 \%$ respectively all through the financial reform periods. Volumes of loan disbursed by bank to agricultural sector and the reforms had a significant impact on farmers' output.

\section{Data and Methodology}

The study adapted the model by [23], stated thus:

$$
\operatorname{MGDPt}=f\left(\mathrm{BF}_{\mathrm{t}}, \mathrm{LC}_{\mathrm{t}}, \mathrm{A}_{\mathrm{t}}\right) .
$$


Where:

$\mathrm{MGDP}_{\mathrm{t}}=$ Manufacturing Output Growth

$\mathrm{BF}=$ Measure of Banking Reforms proxied by Real Interest Rate

$\mathrm{LC}=$ Lending capacity of the banking system measured by ratio of Deposit Money Bank's assets to total banking assets

$\mathrm{A}=$ Conditioning variables which would also determine the productivity of the invested capital.

Owolabi S. A., Olanrewaju G. O and OKWU A. T., in the present study, the model is slightly modified to accommodate the other variables in the study as follow [23]:

$$
\mathrm{ASOPG}=f(\mathrm{BSRV})
$$

Where:

ASOPG means Agricultural Sector Output Growth proxied by GDP (Agricultural components) as dependent variable.

BSRV: Banking Sector Reforms Variables.

The structural model for this study are expressed in the equations below:

$$
\mathrm{ASOPG}=f(\mathrm{ABCAS}, \mathrm{DMBLDR}, \mathrm{IRS}, \mathrm{REER})
$$

Where:

ASOPG: Agricultural sector output growth.

ABCAS: Aggregate bank credit to the agricultural sector

DMBLDR: Deposit Money Bank Loan-to-deposits ratio

IRS: Interest Rate Spread (Rather than interest rate per se, as used by [8], we use interest rate spread (IRS), in view of the fact that interest rate a bisectional phenomenon which can affect savings on the one hand and borrowing and therefore investment on the other.

REER: Real Effective Exchange Rate Index.

$\varepsilon_{t}$ : error term

Thus, the explicit model of equation is stated as:

$$
\mathrm{ASOPGt}=(\mathrm{ABCAS}+\mathrm{DMBLDR}+\mathrm{IRS}+\mathrm{REER}
$$

In the stochastic form equ (3) becomes:

$$
\begin{aligned}
& \text { ASOPAt }=\beta 0+ \beta_{1} \text { ABCAS }_{t}+\beta_{2} \text { DMBLDR }_{t}+\beta_{3} \text { IRS }_{t}+\beta_{4} \text { REER }_{t} \\
&+\varepsilon t
\end{aligned}
$$

However, considering the recommendation of McClearly and Hay (1980) the variables in the models will be transformed into a logarithm form in order to remedy the heterogeneity of variance to avoid porous results.

Thus, the log function gives us:

$$
\begin{aligned}
& \log \text { ASOP }_{\mathrm{t}}=\beta 0+\log \beta_{1} \mathrm{ABCAS}_{\mathrm{t}}+\log \beta_{2} \mathrm{DMBLDR}_{\mathrm{t}}+ \\
& \log \beta_{3} \mathrm{IRS}_{\mathrm{t}}+\log \beta_{4} \mathrm{REER}_{\mathrm{t}}+\varepsilon_{\mathrm{t}}
\end{aligned}
$$

In above equations; above $\beta_{0}, \beta_{1}, \beta_{2}, \beta_{3}, \beta_{4}$, are parameters to be estimated while $\varepsilon_{\mathrm{t}}$ is the error term.

\subsection{Method of Data Analysis}

The data was analyzed using the Two-Stage Least Squares (2SLS) technique. Two-Stage least squares (2SLS) is a statistical technique that uses instrumental variables that are uncorrelated with the error terms to compute estimated values of problematic predictor (s), (the first stage), and then uses those computed values to estimate a linear regression model of the dependent variable (the second stage). Basically, the 2SLS technique is used when there are feedback loops in a model, (that is, when there is/are intermediate or intervening variables), and or when the dependent variable's error terms are correlated with the independent variables. The choice of the 2SLS for this study is informed by the fact that, banking reforms were expected to affect certain variables IRS, Loan/Deposit ratio, etc. as intermediate variables before impact on agricultural sector output.

\subsection{Apriori Expectation}

On apriori, Aggregate Bank Credit to the Agricultural Sector (ABCAS), Deposit Money Bank Loan-to-Deposits Ratio (DMBLDR), is expected to be positive because an increase in ABCAS and DMBLDR will lead to increase in the agricultural output. On the other hand, Interest Rate Spread (IRS) and Real Effective Exchange Rate Index (REER) is expected to be negative in that, increases in IRS and REER potentially reduces the value of investable funds thereby leading to a reduction in the level of agricultural output.

\section{Results and Discussions}

\subsection{Unit Root Tests}

Unit root test is carried out to determine if the variables are stationary and if not, to determine their order of cointegration (i.e. number of times they are to be differenced to achieve stationarity).

Table 1. Results of Unit Root Test using Augmented Dickey Fuller (ADF) TEST.

\begin{tabular}{llllll}
\hline At level & \multicolumn{5}{c}{ At first difference } \\
\hline Variables & Statistic & Crit.@5\% & Statistic & Crit.@5\% & Decision \\
\hline ASOPG & -1.247431 & -3.0522 & $-4.264039^{*}$ & -3.7597 & I(1) \\
ABCAS & -0.477420 & -3.0522 & $-7.854273^{*}$ & -3.7597 & I(1) \\
DMBLDR & -4.064082 & -3.0522 & $-4.841248^{*}$ & -3.7597 & I(1) \\
IRS & -4.107204 & -3.0522 & $-6.510078^{*}$ & -3.7597 & I(1) \\
REER & -2.071828 & -3.0522 & $-3.917263^{*}$ & -3.7597 & I(1) \\
\hline
\end{tabular}

Note: * indicates significance at 5\% level 
The unit roots test result at levels is reported in Table 1. The ADF test rejected the null hypothesis of the presence of unit root at levels for DMBLDR and IRS implying that DMBLDR and IRS series are integrated of not cointegrated at levels but at order one, that is $I(1)$. Equally, the ADF test rejected the null hypothesis of unit root for agricultural sector performance (ASOPG), ABCAS and real effective exchange rate index (REER) at first difference, suggesting that the series are integrated of order one, that is I(1). These findings further support the application of the Two-Stage Least Squares regression.

Analysis of Results using Two-Stage Least Squares (2STLS) is presented in Table 2.

Table 2. Results of Two-Stage Least squares on the Effect of Banking Sector Reform on Agricultural Performance.

\begin{tabular}{|c|c|c|c|c|}
\hline \multicolumn{5}{|c|}{ Dependent Variable: ASOPG } \\
\hline \multicolumn{5}{|c|}{ Method: Two-Stage Least Squares } \\
\hline \multicolumn{5}{|c|}{ Instrument specification: ABCAS DMBLDR IRS REER } \\
\hline Variable & Coefficient & Std. Error & t-Statistic & Prob. \\
\hline ABCAS & 29.01044 & 3.677761 & 7.888071 & 0.0000 \\
\hline DMBLDR & 8.412134 & 28.49162 & 0.295249 & 0.7700 \\
\hline IRS & -16.78985 & 156.0754 & -0.107575 & 0.9151 \\
\hline REER & 33.10017 & 7.365516 & 4.493938 & 0.0001 \\
\hline $\mathrm{C}$ & -633.1663 & 2457.548 & -0.257641 & 0.7986 \\
\hline R-squared & 0.965924 & Mean dependent var & & 8059.577 \\
\hline Adjusted R-squared & 0.961056 & S. D. dependent var & & 9240.964 \\
\hline S. E. of regression & 1823.632 & Sum squared resid & & 93117753 \\
\hline F-statistic & 198.4235 & Durbin-Watson stat & & 0.646468 \\
\hline Prob (F-statistic) & 0.000000 & Second-Stage SSR & & 93117753 \\
\hline J-statistic & $1.40 \mathrm{E}-41$ & Instrument rank & & 4 \\
\hline
\end{tabular}

Source: Author's computation using Eviews 10

Evidently, the results showed that three of the banking sector reform variables (ABCAS, DMBLDR and REER) have positive effect on agricultural sector output growth while one of the banking sector variables (IRS) indicated a negative effect on agricultural sector output growth.

The result of Two-Stage Least squares, as contained in table 2 showed mixed findings as regards the effect of the explanatory variables on the output growth of the agricultural sector. The result of Aggregate Bank Credit to the Agricultural Sector (ABCAS) on the Agricultural Sector Output Growth (ASOPG) showed that $29 \%$ of the total variation in the performance of the agricultural sector growth is determined by ABCAS and that there is a positive and significant effect of ABCAS on ASOPG even at $1 \%$ significant level.

Deposit Money Banks Loan to Deposit ratio also affect the availability of credit to different sectors of the economy in that it can be expansionary or contractionary. As regards the empirical findings, as indicated in table 2 above, there exist a positive relationship between ASOPG and DMBLDR. Specifically, the result showed that $8.4 \%$ of the total variations in the ASOPG is caused by the DMBLDR however the relationship is not significant at $5 \%$ with a $\mathrm{P}$ value of 0.7700 .

The empirical findings (Table 2) indicates that there is a negative but insignificant relationship between IRS and ASOP with a coefficient of -16.79 and a P-value of 0.92 respectively. Real effective exchange rate, showed a positive and significant relationship with ASOPG with a coefficient of 33.10 and a pvalue of 0.0001 respectively. Thus, the overall result of the study suggest that banking sector reforms generally contribute positively and significantly to the growth of agricultural sector in Nigeria in the period 1986-2019.
To avert the problem of instrumental variable trap, the explanatory variables of the model also enter the model as instruments. The high values of the F-statistic as well as the $\mathrm{j}$-statistics indicate that the instruments are adequate and have contributed to explaining the effect of the independent variables on the dependent variable. Furthermore, the Adjusted R-squared value of 0.96 implies that about $96 \%$ of the variation in agricultural sector output in Nigeria is jointly explained by banking sector variables. This is expected because most of the large-scale investment in agriculture in Nigeria is financed by loans from the Deposit Money banks and other development banks such as the Bank of Agriculture or interventions from the Central Bank of Nigeria such as the anchors borrowers programme amongst others.

\subsection{Diagnostics and Stability Tests}

To confirm the reliability and stability of the 2STLS estimates, the study conducted the diagnostic tests for the residuals as well as the stability test of the coefficients and the results presented in Table 3. For the residuals, the study used the Breusch-Godfrey LM test of autocorrelation and the ARCH test for the conditional heteroscedasticity. Also, the study used the Ramsey Reset test in testing for the model misspecification and stability of the coefficients.

Table 3. Result of the Diagnostic Tests.

\begin{tabular}{lll}
\hline Test statistics & F-statistic & P-value \\
\hline Serial Correlation $\left(\chi^{2}\right.$ SERIAL $)$ & 0.2347 & 0.2318 \\
Heteroskedasticity $\left(\chi^{2}\right.$ ARCH $)$ & 0.1309 & 0.6732 \\
Ramsey Reset $\left(\chi^{2}\right.$ RESET $)$ & 1.5536 & 0.1074 \\
\hline
\end{tabular}

Source: Author's compilation using E-views 10.0 
The results of the diagnostic tests in Table 3 showed that the model is free from serial or autocorrelation and heteroscedasticity since the P-values of both statistics are greater than 0.05 . Similarly, the result of the Ramsay RESET also report a P-value greater than 0.05 which implies that, the functional form of the models is correctly specified and the coefficient are stable over time.

\section{Summary, Conclusions and Recommendation}

\subsection{Summary of Findings}

This study set out to assess the effect of banking reforms on the growth of agricultural sector in Nigeria in the period 1986-2019. Banking reforms in Nigeria were embarked upon repeatedly in the period under review, all with the aim of ensuring a more dynamic, more robust and more impactful banking system. As a major contributor to the Nigerian economy, agricultural sector was expected to be impacted by these reforms too. Thirty-four (34) year time series data were analysed with 2STLS techniques with the dependent variable being agricultural sector output growth and ASOPG as a proxy. The expected causal variables were as follows: ABCAS (Aggregate Bank credit to the agricultural sector), DMBLDR (Deposit Money Bank Loan-to-Deposits Ratio), IRS (Interest Rate Spread), and REER (Real effective Exchange Rate Index).

The research findings are that:

1) aggregate bank lending to the agricultural sector (ABCAS) had positive and significant effect on agricultural output grow with co-efficient of 29.00;

2) real effective exchange rate (REER) also had positive and significant effect on agricultural sector output grow; and

3) deposit money banks' loan to deposit ratio had a positive but non-significant impact on agricultural sector output growth while interest rate spread has negative but non-significant impact on agricultural output growth.

\subsection{Conclusion}

With the above findings, the study has confirmed that banking sector reforms undertaken from around the middle of 1980s to the tail ended of the second decade of the third millennium has had positive and significant impact on agricultural sector output growth. These findings are in consonance with Ekin and Onukwuru (2018) and Agenson and Eyo (2019) among others. The findings are however at variane with Onyema and Agada (2018).

\subsection{Recommendations}

Based on the above findings; the following recommendations are proffered:

1) that a more structured reform programme in the banking and financial sector that prioritizes credit to the agricultural sector should be promoted. Banking reform should target identifiable and specific objectives, key agents and actors as well as anchored on measurable benchmarks; and

2) harvesting and harnessing private sector finances into the agricultural sector with appropriate linkages with manufacturing and export sectors will help to engender agricultural value-chain extension and enhancement;

3) financing for modern, gigantic and mechanized farming, anchored on agro-manufacturing, should be undertaken. This could be organized through collaborative efforts among deposit money banks, large scale agro-investors; (domestic and foreign), as well as capital market funds suppliers.

\section{References}

[1] Adesanya, B. and Obademi, O. E (2016). Banking Sector Reforms and Economic Growth: Evidence from Nigeria. International Journal of Social Science and Economic Research, 1 (10), 1705-1717.

[2] Ali, J I., Jatau S. and Ekpe, M. J. (2016). Financial Intermediation and Agricultural Output in Nigeria: An Impact Analysis of Deposit Money Banks' Credit. International Journal of Agricultural Economics. 1 (1), 16-25.

[3] Ali, J. I. (2015). Effect of Banking Sector Reforms on the Performance of Deposit Money Banks' in Nigeria. A Thesis Submitted to the Department of Banking and Finance University of Agriculture Makurdi.

[4] Anthony, O., Gabriel, E. E. and Arikpo, O. F. (2015). The contribution of deposit money banks on the growth of the agricultural sector in Nigeria. Advances in Social Sciences Research Journal, 3 (2), 33-42.

[5] Allen, F. and Gale, D. (2000). Competition and Financial Stability. Journal of Money, Credit and Banking, 36 (4), 453480 .

[6] Beck, T., Demirgüç-Kunt, A. and Levine, R. (2000). Bank Concentration and Fragility: Impact and Mechanics. Retrieved from http://www.nber.org/books/risk/beck-et-al1215-04.pdf.

[7] Bagehot, W. (1873). Lombard Street: A Description of the Money Market. Retrieved from https://EconPapers.repec.org/RePEc:hay:hetboo:bagehot1873.

[8] Chris, O. U, Mbat, D. O and Stephen, B. D. (2016). The Effect of Commercial Banks' Credit on Agricultural Production in Nigeria. Journal of Finance and Accounting. 1 (4) 1-10.

[9] Ekine, D I. and Onukwuru F. M. (2018). Deposit Money Banks' Credit and Agricultural Sector Performance in Nigeria. Gjournals. 8 (3), 65-73.

[10] Gheernert, L and Mansour, J. M. (2005). Impact of private capital flows on economic growth and development centre Emile Bergheim, CEB Working Paper No 05/003.

[11] Gibson, H. D and Tsakalotos, E. (1994). The scope and limits of financial liberalisation in developing countries: A critical survey. Retrieved from https://doi.org/10.1080/00220389408422329. 
[12] Harris, D. R. and D. Q. Fuller, (2014). Agriculture Definition and overview. In Encyclopaedia of Global Archaeology (Claire Smith Ed.). Springer New York 104-113.

[13] Jhingan, M. L. (2004). Monetary Economics (6th Ed.). New Delhi, India: Vrinda Publications Ltd.

[14] Kwanashie, M., Ajilima, I. and Garba, A. (1998). The Nigerian Economy: Response of agriculture to adjustment policies. AERC Research paper 78, African Economic Research Consortium, Nairobi March 1998.

[15] Kareem, R. O, Osisanya, S. O and Isiaq, T. S (2017). Commercial Bank Financing and Agricultural Sector Output inNigeria (1980-2014). Journal of Research in Business, Economics and Management. 8 (1), 1302-1310.

[16] FMAWNRD (nd). Agricultural Policy for Nigeria. Federal Ministry of Agriculture, Water Resources and Rural Development - Abuja.

[17] Keyns, J. M. (1936). The General Theory of Employment, Graff, H. M. 2001. Interest and Money in Financial Development and Economic presented at the $30^{\text {th }}$ Annual conference of Economists (Sept 24th).

[18] Lemo, T. (2005). Regulatory oversight and stakeholder protection, A paper presented at BGLmerger and acquisition interaction seminar, held at Eko Hotel and Suit, V. I, Lagos, Nigeria, June 24. Monetary Economics, 32, 1-30.

[19] Levine, R. (1997). Financial Development and Economic Growth: Views and Agenda. Journal of Economic Literature, 35, 688-726.

[20] McKinnon, R. I. (1973). Money and Capital in Economic Development. Washington D.C.: Brookings Institution.

[21] Okafor, F. O. (2011). 50 years of Banking Sector Reforms in Nigeria (1960-2010), Past Lessons and Future Imperatives, Enugu, Ezu Book Ltd.
[22] Onyema, J. I. \& Agada. R. C. (2018). Deposit Money Banks, Agricultural Financing and Growth of the Agricultural Sector in Nigeria: 1981-2015. International Journal of Innovative Financeand Economics Research 6 (3), 14-2.

[23] Owolabi S. A., Olanrewaju G. O and OKWU A. T. (2013). The Causality between Banking Sector Reforms and Sectoral Output Growth: Empirical Evidence from Nigeria, International Journal of Research in Management Sciences, 1 (1) $1-12$.

[24] Omankhanlen, A. E. (2012). The Financial Sector Reforms and their Effect on the Nigerian Economy. Journal of Economy Trans-disciplinarity Cognition, 15 (2), 45-57.

[25] Schumpeter, J. A. (1912). The Theory of Economic Development, tenth printing 2004, Transaction Publishers, New Brunswick, New Jersey.

[26] Shaw, E. S. (1973). Financial Deepening in Economic Development, New York: Oxford University Press.

[27] Sanusi, L. S. (2012). Banking reform and its impact on the Nigerian economy: Being a lecture delivered by Sanusi Lamido Sanusi CBN Governor. University of Warwick's Economic Summit. UK.

[28] Todaro, M. and Smith, S. (1999). Classical Theories in Economic Development: A Comparative Analysis; in M. Todaro and S. Smith (eds). Economic Development, Prentice Hall Inc. NY.

[29] Uzomba, P. C, Chukwu, S. N. and Jumbo, G. A. \& Nwankwo, N. U. (2014). An Inquiring into the Impact of Deposit Money Banks' Loans/Advances on Agricultural Sector in Nigeria 1980 - 2011. International Review of Social Sciences and Humanities, 7 (2), 130-139. 